\title{
Two Mechanisms of Land Property Rights Affecting Rural-Urban Migration in China
}

\author{
Xiao Wang ${ }^{1}$ \\ ${ }^{1}$ Freeman School of Business Tulane University Beijing China \\ 18605375586@163.com
}

\begin{abstract}
This paper gives a general description the land system in China, expounds on the impact of land policy, including land rent policy and government land expropriation policy, on the decision of rural households to move to urban areas. Analyzed data from about 23,000 households with STATA and summarized the effects of these two policies, as well as factors such as age, gender, health status, and political affiliation, on the migration decisions of rural households.
\end{abstract}

Keywords: HRS, Land Property Rights, Rural-Urban Migration, Probit Model.

\section{BACKGROUND}

\subsection{China's Land System}

The history of economic development in New China is also a chronicle of land property rights. All achievements in China today are inseparable from changes in the land system history. The current population migration under industrialization and urbanization mainly flows from mountainous areas to plains, from rural areas to cities, and from impoverished areas to developed areas[1]. Changes in the land system have affected countless urban and rural residents' choices for immigrants. China's land property arrangement has also become a significant factor with far-reaching influence on the Chinese economy and society.

\subsubsection{China Land System: Urban and Rural}

China's urbanization rate reached $60 \%$ in 2019 , and some scholars are optimistic that China's urbanization rate will go up to about $80 \%$ in 2030 , which is the average level of developed countries[2]. Urbanization must rely on land property rights. In the process of urbanization, land property plays an important role. The adjustment of industrial structure, the agglomeration of population, and the construction of infrastructure must be realized through the re-allocation of land[3]. China's current urban land system originated from Article 10 of the Constitution promulgated on December 4, 1982: "The land in cities belongs to the state." Ownership belongs to the state, which is the basic point of China's urban land system. Subsequently, the constitutional amendment introduced in 1988 deleted the provision that land cannot be leased, and stipulated that land use rights can be transferred, which established a legal basis for the land transaction market. In 1990, the State Council issued the Interim Regulations on the Assignment and Transfer of Urban State-owned Land Use Rights, established the regulations for the transfer of urban land. But the land transfer method is based mainly on the agreement. In 1992, to solve the problems of establishing a socialist market economy system, the State Council decided that the state should monopolize the primary market of urban land and implement a limited-term land use right transfer system. The State Council also required a strict land examination and approval system, stipulating the scope of land allocated by the government. In this way, other departments can get land only by allocation. So far, China's modern urban land system has formed: based on state ownership, the right to use is allowed to be obtained in two ways: allocation and transfer.

China's rural land system has undergone four major changes. The first was the land reform from September 1949 to the spring of 1953. In this movement, more than 300 million landless farmers obtained more than 700 million mu of land and were exempted from 35 billion kilograms of grain rent, and in fact, became a small private owner. According to statistics, China's total agricultural output value in 1952 increased by $48.3 \%$ compared to 1949 , grain output increased by $44.8 \%$, cotton output increased by $193.4 \%$, and oil production 
increased by $168.1 \%$ [4]. However, in this movement, farmers have not obtained the real exclusive land property rights actually [5]. The second change was from 1953 to 1978 , the stage of cooperation and collective management. The adjustment of the land system at this stage has gone through three periods which are primary, advanced, and people's communes. Chinese rural land has gradually changed from decentralized management to collective management [6]. The period from 1958 to 1978 witnessed the third change. Since the founding of China, the growth of agricultural production has been slowly for 20 years. In the first two decades, the average annual growth of China's agricultural output value was only $2.6 \%$. The average annual growth of grain production was $2.3 \%$. The average annual growth of cotton production was $1.4 \%$. The average annual growth of oil production was $1.1 \%$ [7]. In the end, the former rural land system was replaced by the household contract responsibility system (HRS) in 1979. This policy is still in use today, but some scholars believe that the HRS policy in the new era highlights some drawbacks, considering the need for the large-scale development of agriculture and rural areas. The new trend of labor migration is to optimize the allocation of land and labor resources, promote production agglomeration with factor concentration, and promote rural revitalization [8]. In recent decades, rural land reform has combined farmers' spontaneous innovation and national policies. China established a rural land policy that combines collective ownership and farmers' long-term guaranteed land use rights.

\subsubsection{HRS Land Property Right Characteristics}

In the winter of 1978, Xiaogang village, administered by Xiaoxihe town in Fengyang County, Chuzhou City, Anhui province suffered severe famine. To survive, 18 villagers secretly signed an agreement to distribute the land of the production team to each family to manage separately. As a result, there was a bumper harvest in the spring of the following year. The countermeasures under this desperate situation led to the formation of the household contract responsibility system(HRS) that has been in use today. To protect farmers' land management rights, the Constitution of the People's Republic of China adopted in 1982 stipulates that, except for those owned by the state as stipulated by law, land in rural and suburban areas, homesteads, private plots, and private hills are collectively owned. The Land Administration Law of the People's Republic of China passed in June 1986 further detailed the requirements of the Constitution on the land system.

The implementation of the household contract responsibility system has corrected the long-standing shortcomings of high concentration and excessive monotony of management, liberated the productivity of China's rural areas, and created the second golden age in the history of China's agricultural development. HRS fully embodies the socialist public ownership system. The superiority of the policy provides conditions for farmers to live on their land for generations. Under HRS, the total grain output increased from 304.765 million tons in 1978 to 601.94 million tons in 2013. Chinese agriculture feeds $22 \%$ of the world's population with $7 \%$ of the world's arable land[9].

But by the mid-1990s, the average farmland owned by Chinese farmers was only six mu. Such a dispersed farmland structure is not conducive to large-scale investment by farmers, and the results of agricultural technological progress cannot be represented, which in turn inhibits the advancement of agricultural science and technology. Moreover, due to the dispersed farmland structure, lots of trouble occurs in daily operation and management, and lots of labor and material resources were wasted. At the same time, farmers only have the right to use the land but no ownership. When farmers cannot dispose of land freely, on the one hand, the largescale operation of farmland is restricted, on the other hand, the freedom of farmers to choose the way of earning a living is restricted. To avoid land expropriation, many rural households give the land to the old people, women, and children for farming and regard it as an obligation to manage the land. Some farmers linger between staying on farmland and working in cities, which not only wastes the land but also restricts the rural population's outflow and free choice of employment to a certain extent. Local government departments often arbitrarily adjust the land contracts by farmers, shorten the contract period, suspend contracts, take back the land contracted by farmers, and illegally expropriate farmland. Due to the unstable possession and cultivation of land by farmers, farmers lack the enthusiasm for long-term investment in land, short-term land management behavior is inevitable, and land resources are in predatory managed. This lack of persistence in the land will inevitably lead to the inability to improve the production conditions of agricultural industrialization, the inability to increase agricultural productivity, the slow growth of farmers' income, and the increased motivation of rural populations to move to cities.

\subsection{The Impacts of Migration}

The economic effects of migration should be discussed separately. In a nutshell, places where people migrate in can get a lot of cheap labor, while promoting commodity circulation and economic development, and driving the development of the tertiary industry; Adverse effects on the places where people migrate in generally include huge pressure on public facilities, urban management, and the ecological environment. 
For places where people migrate out, the benefits of population migration mainly lie in strengthening the local social, economic, and technological connections with the outside world, and alleviating excessive pressure on the land; The unfavorable factor is the lack of labor, and the local demographic structure may be negatively affected, such as the shortage of young and middle-aged workforce and the aging of the population.

\section{LITERATURE}

\subsection{Land Property Right}

The modern Chinese land ownership system is a parallel system of collective ownership and state ownership. Many scholars have done in-depth and diversified research on land ownership because of the profound impact of land ownership [10][11][12][13]. According to the above literature, China's rural land ownership has undergone four major changes. As a vital system in this historical process, rural collective land ownership is essentially a form of social organization and a systematic arrangement of China's social structure. As a form of public ownership, collective ownership is the basis of the socialist system with Chinese characteristics[14]. The rural land system shall be established under the following principles: the principle of constant collective ownership of rural land, the principle of reform and innovation and gradual progress, the principle of balance between fairness and efficiency, the principle of the close connection between urban and rural land property rights systems, and the principle of promoting the perfection of the market economic system[15]. The dual land system in urban and rural areas has severely restricted the integration of social and economic development in China. The Chinese government is actively promoting the reforms of rural agricultural land, collective operating construction land, and homestead to remove the dual institutional barriers that hinder the establishment of an integrated land trading market[16]. In the process of leading the land reform and privatization movement, the state has cast its will into the private property rights of rural households. When the will of the state changes, the rural land property system changes accordingly[17]. Despite such tremendous changes, China's rural land property rights system is still imperfect, and there are many discussions about the innovation of rural land property rights system in academia. At present, the relevant state laws and regulations specify the farmers can get such as land contract right, the right of management, transfer, remuneration, mortgage, inheritance, the disposition of products, or compensation for land expropriation.However, for a long time, people have not traditionally believed that land belongs to the people, which has led to the infringement of farmers' fundamental land rights[18]. Rural people living in such a social environment inevitably have anxiety, which brings a series of social problems, including population migration due to land ownership arrangements.

\subsection{The Mechanism of Land Property Right Impacting Migration}

\subsubsection{Rural Land Tenure in China}

China became the world's second-largest economy in 2010, and if China maintains a GDP growth rate of $8 \%$, it is expected to challenge the United States for supremacy within a decad. However, developed countries in Europe and the United States are increasingly handicapping China's development through technological bottlenecks. Meanwhile, structural transformation, lack of domestic demand, lack of jobs, poverty, rural issues, and rising crime, along with the looming middle-income trap, have put China in difficulty. The best way to solve these intractable problems is to increase total factor productivity. The increase in total factor productivity can only rely on economies of scale, technological progress, and efficiency improvements, that is, urbanization, the agglomeration of population and other factors of production[19]. At around 60\%, China's urbanization rate lags far behind that of the United States, which has an urbanization rate of $82.7 \%$ by 2020 . The process of urbanization will be accompanied by the migration of hundreds of millions of people, in which the rural land system will play a decisive role. In China, agricultural land and woodland are subject to so-called "quasi-private" property rights[20]. Land rights can only be transferred temporarily, rather than sold outright, which limits the use of land to finance migration or as collateral for credit.

In rural China, the HRS system is implemented, and households obtain land use rights through household contract operation. Under this system, the land is officially owned collectively but is allocated to rural households, who are responsible for their agricultural production. When the land ownership system was first introduced, land could not be transferred between households but had to be periodically redistributed at the discretion of the village head.The Rural Land Contracting Law of 2002 has improved the provisions of the Constitution on the basic rural land operation system. This law takes "household contract management as the basis and implements a two-tier management system combining unification and division", and takes the "separation of the two rights" as the theoretical basis to construct the land contract and management rights system with Chinese characteristics[21]. But there is evidence that rural households in China are still at risk of land redistribution: out of a sample of 8,000 households in 800 villages in China, about one-third experienced land redistribution between 2002 and 2004 [22].

Because of the rapid economic development, rapid urban expansion, high population density, and 
insufficient construction land, many local governments meet the needs of construction land through compulsory land expropriation, and the insecurity of land use rights has intensified[23]. Meanwhile, the narrow compensation range of land expropriation, the low compensation standard, the unscientific measurement method, and the improper intervention of the government in the measurement process make the rural families of the land expropriated bear too great a burden. Also, in most mature market economies, the concept of "just" compensation is related to the market value of land, but in rural China, the lack of clear property rights or an effective land market makes this mechanism difficult to achieve [24].

\subsubsection{Theoretical Hypotheses about the Impact of Land Tenure on the Household Migration} Decision

Regarding the impact of land property arrangements on the regional migration decision of rural households, there may be two differents mechanisms: market mechanism and government mechanism.

With the accelerated development of China's newtype urbanization, the expropriation of farmers' land is also rapidly increasing. For example, from 2012 to 2017 , China's urbanization rate increased from $52.6 \%$ to $58.5 \%$, and more than 80 million agricultural migrants became urban residents[25]. If migration leads to an increase in the risk of land acquisition, then the first link between land use rights and labor distribution decisions is created. When migration leads to a reduction in family size, the labor of some rural families may give up working in cities to retain land use rights; When the land is expropriated for urban construction or infrastructure construction, these families will feel more insecure [23]. Under this scenario, families have people who migrated to urban areas will consider the increased risk of land expropriation in the coming period as a result of reduced family size. The effect of the increased risk of expropriation on migration can be seen as the negative effect of higher taxes on migration. However, we also consider the effect that higher security of land rights reduces the overall risk of land expropriation for rural households. Reducing the likelihood of land acquisition is akin to reducing immigration taxes, thereby increasing incentives for migration[26]. However, less land expropriation will lead to more land retained by rural households and thus more Labour needed, offsetting some of the migration incentives. On the contrary, the higher risk of land expropriation increases the incentive for rural households to stay in the countryside. Thus, in our simple model, land rights associated with improved security of land tenure may have both positive and negative net effects on migration simultaneously.

Whether the family has land lease rights is the second aspect of the land property that may affect migration. If rural households can rent the land out, the opportunity cost of corresponding migration will increase, and labor will be restricted to agricultural production in rural areas, thereby reducing migration incentives. Conversely, if rural households can not rent the land out, the marginal productivity of land will be balanced to the land rental rate, and the marginal productivity of labor will be balanced to the non-agricultural wage rate. With the increase in land lease rights, the opportunity cost of migration decreases, resulting in a higher migration rate.

To sum up, according to the prediction of the theoretical model of labor allocation in rural households, the confirmation of land lease rights has a clear positive incentive for the rural population to migrate to cities; While the reduced risk of government land acquisition has a dual effect. On the one hand, improving land security promotes the flow of rural labor to cities and towns. On the other hand, more arable land attracts the return of labor from urban to rural areas.

In conclusion, according to the prediction of the theoretical model of rural household labor allocation, the confirmation of land lease has a clear positive incentive to rural population migration to urban areas; The reduced risk of land acquisition by the government plays a dual role. On the one hand, it promotes the flow of rural workforce to cities by improving land security; on the other hand, more land attracts the backflow of workforce from urban areas to the countryside.

\section{EMPIRICAL ANALYSIS}

\subsection{Data}

The China Health and Retirement Longitudinal Study (CHARLS) is a set of high-quality micro-data representing the families and individuals of middle-aged and elderly people aged 45 and over in China from the National Development Research Institute of Peking University. CHARLS is used to analyze the aging of the population in China, and to promote interdisciplinary research on the issue of aging. The CHARLS national baseline survey was launched in 2011, covering 150 county-level units, 450 village-level units, and about 17,000 in 10,000 households. Samples in CHARLS will be tracked every two to three years in the future, and one year after the survey is over, the data will be released to the academic community.

This article selects the factors that the author believes are most likely to affect the migration of rural residents to urban areas for analysis. The collected samples are from 2013 and 2014 data sets. During the data validity check, the author noticed that the maximum age of the surveyed object was 146. After manually excluded the samples older than 110 years old, the upper age limit after removal was 99 years old. 
Table1. Descriptive Statistics of Regression Variables

\begin{tabular}{clrrr}
\hline Variable & \multicolumn{1}{c}{ Description } & N & Mean & Std. Dev. \\
\hline migration & $\begin{array}{l}\text { 1= Have lived in a non-domicile place for more } \\
\text { than 6 months }\end{array}$ & 7164 & 0.577 & 0.494 \\
chuzubi & $\begin{array}{l}\text { Ratio of area of rented land to all the land of the } \\
\text { household }\end{array}$ & 6435 & 0.093 & 0.266 \\
$\begin{array}{c}\text { expropriation } \\
\text { age }\end{array}$ & 1= went through land expropriation after 1978 & 10825 & 0.135 & 0.341 \\
gender & Age & 20620 & 58.823 & 10.881 \\
health & O=female 1=male & 20650 & 0.475 & 0.499 \\
party & Self-evaluation of health: 1=good; 5=poor & 9286 & 3.024 & 0.978 \\
han & 1= The communist party member & 18556 & 0.108 & 0.31 \\
hukou & 1= The han nationality ; 0= Ethnic minorities & 18519 & 0.923 & 0.266 \\
$\begin{array}{c}\text { edu } \\
\text { logincome }\end{array}$ & Education from 1=lowest to 5=highest & 18551 & 1.247 & 0.46 \\
logliability & Log income & 20482 & 1.575 & 0.837 \\
poverty & Log liability & 10870 & 6.169 & 1.303 \\
hospital & 1=once was starved in childhood & 14459 & 0.691 & 2.586 \\
marital & 1= have convenient place to see a doctor & 13986 & 0.697 & 0.459 \\
IV & 1=married ; 6=never married & 13998 & 0.896 & 0.305 \\
\hline
\end{tabular}

Table 1 contains the descriptive statistics for the dependent variable and all the independent variables. In the sample, more than half of the residents had experienced what we define as migration (living in a place other than their birthplace for six months or more); The majority of respondents are Han, with only 7.7 percent from ethnic minorities. Their average age is close to 60 , and women account for slightly more than men. Only one in ten Communist Party members; Marital status is generally stable, but the level of education is not high, and the self-evaluation of health status is low.

\subsection{Identification Strategy}

In order to model this survey, I used the multiple linear regression formula:

$$
\square=\square 0+\square 1 \square 1_{1}+\cdots+\square \square \square \square+\square
$$

This paper uses a multiple linear regression model as the identification strategy to study the impact of land property rights on the migration tendency of rural household members. Using migration as the $\mathrm{Y}$ variable in the regression analysis. Take the two land rights arrangements as $\mathrm{X}$ variables respectively. Some other variables that may be related to the migration of rural families, such as age, gender, health status, education level, and family income, were selected as auxiliary variables for regression model analysis. This is also a Probit model using a binary dependent variable Y, $\square \square$ can be a dummy variable.

\subsection{Market Mechanism of Land Property Right Change on Migration}

\subsubsection{Basic Regression}

To assess the effect of market mechanisms on migration, we use the ratio of leased land area to household land area as a key variable, while selecting age, sex, education level, income, and health status as auxiliary variables. The PROBIT model was used to assess the impact of increased or improved land tenure on migration, using the tool STATA15.

The model of land lease and population migration is expressed as follows:

Migration $=\beta_{0}+\beta_{1} \square$ huzubi $+\beta_{2}$ age $+\beta_{3}$ gender + $\beta 4$ edu $+\beta 5$ logincome $+\beta 6$ logliability $+\beta$ 7health $+\square$

After regression analysis, we obtained the data of the basic regression column in Table 2 . It can be seen that chuzubi, age, gender, and logincome are significant to migration, and Chuzubi's coefficient is positive, which can preliminarily conclude that chuzubi is positively correlated with migration. However, in order to draw accurate and rigorous conclusions, a robustness test of the fundamental regression is needed.

\subsubsection{Robustness Checks}

To test the robustness of the basic regression, we added some new variables to the regression model, such as political status, ethnicity, childhood experience of starvation, access to medical care, and marital status.

After adding the new variables, Chuzubi is still significant about migration, so it can be confirmed that 
land lease has a positive correlation with population migration. Besides, there is a negative correlation between age and population migration, indicating that young people have a stronger possibility of population migration than the elderly. Gender is positively correlated with population migration, indicating that males are more likely than females to leave rural areas to seek opportunities in urban areas. Income and a stable marriage for a person can also be factors that promote migration; It is worth noting that political status presents a very significant negative correlation with population migration. This may be because in rural society, Communist Party members have a high social status and job satisfaction, and are not willing to give up their jobs to seek new opportunities in cities and towns, so more Communist Party members stay in the local areas.

Table 2. Probit Estimates of Migration Participation Decision (Market Mechanism)

\begin{tabular}{|c|c|c|c|c|c|}
\hline Variables & $\begin{array}{c}\text { Basic } \\
\text { Regression }\end{array}$ & $\begin{array}{l}\text { Robustness } \\
\text { Check1 }\end{array}$ & $\begin{array}{l}\text { Robustness } \\
\text { Check2 }\end{array}$ & $\begin{array}{c}\text { Robustness } \\
\text { Check3 }\end{array}$ & $\begin{array}{c}\text { Robustness } \\
\text { Check4 }\end{array}$ \\
\hline \multicolumn{6}{|l|}{ migration } \\
\hline \multirow[t]{2}{*}{ chuzubi } & $0.517 *$ & $0.538^{*}$ & $0.688 * *$ & $0.499^{*}$ & $0.725 * *$ \\
\hline & $(-1.85)$ & $(-1.72)$ & $(-2.11)$ & $(-1.65)$ & $(-2.21)$ \\
\hline \multirow[t]{2}{*}{ age } & $-0.035^{* * *}$ & $-0.034 * * *$ & $-0.033^{* * *}$ & $-0.036^{* * *}$ & $-0.039 * * *$ \\
\hline & $(-3.91)$ & $(-3.69)$ & $(-3.27)$ & $(-3.41)$ & $(-3.74)$ \\
\hline \multirow[t]{2}{*}{ gender } & $1.048 * * *$ & $1.195 * * *$ & $1.160 * * *$ & $1.265^{* * * *}$ & $1.263 * * *$ \\
\hline & $(-6.97)$ & $(-7.30)$ & $(-6.37)$ & $(-6.91)$ & $(-7.04)$ \\
\hline \multirow[t]{2}{*}{ edu } & -0.18 & -0.17 & -0.14 & -0.15 & $(-0.12$ \\
\hline & $(-1.58)$ & $(-1.46)$ & $(-1.14)$ & $(-1.21)$ & $(-1.01)$ \\
\hline \multirow[t]{2}{*}{ logincome } & $0.150 * * *$ & $0.168 * * *$ & $0.156^{* * *}$ & $0.152 * * *$ & $0.154 * * *$ \\
\hline & $(-2.90)$ & $(-3.20)$ & $(-2.81)$ & $(-2.73)$ & $(-2.83)$ \\
\hline \multirow[t]{2}{*}{ logliability } & -0.006 & -0.004 & -0.001 & -0.003 & -0.001 \\
\hline & $(-0.28)$ & $(-0.19)$ & $(-0.03)$ & $(-0.15)$ & $(-0.04)$ \\
\hline \multirow[t]{2}{*}{ health } & 0.08 & 0.04 & 0.04 & 0.00 & 0.04 \\
\hline & $(-1.04)$ & $(-0.47)$ & $(-0.43)$ & $(-0.05)$ & $(-0.42)$ \\
\hline \multirow[t]{2}{*}{ party } & & $-0.920 * * *$ & $-0.784 * * *$ & $-0.962 * * *$ & $-0.826^{* * *}$ \\
\hline & & $(-3.73)$ & $(-2.91)$ & $(-3.66)$ & $(-3.14)$ \\
\hline \multirow[t]{2}{*}{ han } & & -0.41 & -0.42 & -0.32 & -0.40 \\
\hline & & $(-1.59)$ & $(-1.61)$ & $(-1.19)$ & $(-1.56)$ \\
\hline \multirow[t]{2}{*}{ poverty } & & & -0.03 & -0.04 & 0.01 \\
\hline & & & $(-0.19)$ & $(-0.23)$ & $(-0.04)$ \\
\hline \multirow[t]{2}{*}{ hospital } & & & & -0.13 & \\
\hline & & & & $(-0.51)$ & \\
\hline \multirow[t]{2}{*}{ marital } & & & & & $0.110^{*}$ \\
\hline & & & & & $(-1.85)$ \\
\hline \multirow[t]{2}{*}{ Constant } & 0.53 & 0.90 & 0.91 & 1.21 & 0.99 \\
\hline & $(-0.75)$ & $(-1.17)$ & $(-1.13)$ & $(-1.46)$ & $(-1.22)$ \\
\hline $\mathrm{N}$ & 369 & 368 & 363 & 359 & 363 \\
\hline
\end{tabular}

* Denotes $10 \%$ significance level.

** Denotes 5\% significance level.

*** Denotes $1 \%$ significance level. 


\subsubsection{Endogenous Checks}

There may not be a simple correlation between the ratio of land leased area to household land area and population movement, and there might be a reverse causal relationship. On the one hand, rural people who have secured more land lease rights are more likely to move to urban areas because they can rent out land to reduce the opportunity cost of leaving agricultural production. On the other hand, people who have decided to move to cities and towns may also be affected by land rent rights. The rent of land leads to an increase in the proportion of leased land, which creates a reverse causality. This is a typical endogeneity problem. Only by eliminating endogeneity can the correlation between chuzubi and migration be determined.

To this end, we set an instrumental variable IV to replace the position of chuzubi in the regression model. This instrumental variable needs to have a strong relationship with the ratio of the area of land leased to the total area of the family's land. But the instrumental variable cannot directly affect population migration or vice versa. To meet these conditions, use whether a household has agricultural production equipment as the instrumental variable IV. Instrumental variable IV is a dummy variable composed of 0 and 1.1 represents that rural households own agricultural production tools. If the family does not have agricultural production tools, they are more likely to rent out the land, otherwise, they are more likely not to rent out the land.

The experiment to eliminate endogeneity is roughly divided into two steps. The first step is to test the correlation between instrumental variable IV and chuzubi. The principle is the same as that of 3.3 .1 basic regression and 3.3.2 robustness test, but in this step of the experiment, did not consider the actual meaning of other auxiliary variables, just as an experimental link. The results of the first step are shown in Table 3. IV and chuzubi are significantly correlated, and IV can be used as an instrumental variable.

Table 3. Estimates of the Rented Land to All Land of the Household (with IV)

\begin{tabular}{|c|c|c|c|}
\hline Variable & Basic Regression & Robustness Check1 & Robustness Check2 \\
\hline \multicolumn{4}{|l|}{ chuzubi } \\
\hline \multirow[t]{2}{*}{ IV } & $-0.137 * *$ & $-0.106^{* * *}$ & $-0.053^{*}$ \\
\hline & $(-2.06)$ & $(-2.68)$ & $(-1.74)$ \\
\hline \multirow[t]{2}{*}{ age } & 0.002 & -0.002 & 0.003 \\
\hline & $(-0.91)$ & $(-0.60)$ & $(-1.08)$ \\
\hline \multirow[t]{2}{*}{ gender } & 0.095 & 0.112 & -0.004 \\
\hline & $(-1.1)$ & $(-1.48)$ & $(-0.13)$ \\
\hline \multirow[t]{2}{*}{ edu } & $0.099 *$ & $0.087 * *$ & 0.027 \\
\hline & $(-1.88)$ & $(-2.27)$ & $(-0.89)$ \\
\hline \multirow[t]{2}{*}{ logincome } & 0.018 & 0.011 & -0.004 \\
\hline & $(-0.74)$ & $(-0.7)$ & $(-0.35)$ \\
\hline \multirow[t]{2}{*}{ han } & 0.067 & 0.05 & -0.028 \\
\hline & $(-1.01)$ & $(-0.94)$ & $(-0.47)$ \\
\hline \multirow[t]{2}{*}{ party } & -0.088 & -0.071 & 0.032 \\
\hline & $(-0.77)$ & $(-0.83)$ & $(-0.49)$ \\
\hline \multirow[t]{2}{*}{ health } & 0 & 0.001 & 0.016 \\
\hline & $(-0.02)$ & $(-0.03)$ & $(-0.74)$ \\
\hline \multirow[t]{2}{*}{ marital } & & $0.063^{*}$ & -0.014 \\
\hline & & $(-1.65)$ & $(-1.40)$ \\
\hline \multirow[t]{2}{*}{ poverty } & & & -0.026 \\
\hline & & & $(-0.65)$ \\
\hline \multirow[t]{2}{*}{ Constant } & -0.269 & -0.116 & -0.053 \\
\hline & $(-0.97)$ & $(-0.63)$ & $(-0.26)$ \\
\hline $\mathrm{N}$ & 485 & 485 & 365 \\
\hline
\end{tabular}

* Denotes $10 \%$ significance level.

** Denotes 5\% significance level.

*** Denotes $1 \%$ significance level. 
The next step is the endogenous elimination experiment. Replace the original main variable chuzubi with the instrumental variable IV, and then perform a round of basic regression and robustness tests. The regression results are shown in Table 4: The replaced chuzubi is still migration Significantly related, so it can prove the hypothesis that land lease rights have a promoting effect on population migration.

Table 4. Estimates of Migration Decision (Market Mechanism Without Endogenous)

\begin{tabular}{|c|c|c|c|}
\hline Variable & Basic Regression & Robustness Check1 & Robustness Check2 \\
\hline \multicolumn{4}{|l|}{ migration } \\
\hline \multirow[t]{2}{*}{ Chuzubi (IV) } & $2.582 * * *$ & $2.833 * * *$ & $3.418 * * *$ \\
\hline & $(-4.08)$ & $(-4.91)$ & $(-4.64)$ \\
\hline \multirow[t]{2}{*}{ age } & $-0.038 * * *$ & $-0.029 * *$ & $-0.032 * *$ \\
\hline & $(-4.14)$ & $(-2.36)$ & $(-2.36)$ \\
\hline \multirow[t]{2}{*}{ gender } & $0.675^{* *}$ & 0.552 & $0.758 *$ \\
\hline & $(-2)$ & $(-1.38)$ & $(-1.76)$ \\
\hline \multirow[t]{2}{*}{ edu } & $-0.355 * *$ & $-0.344 * * *$ & -0.132 \\
\hline & $(-2.43)$ & $(-2.63)$ & $(-1.18)$ \\
\hline \multirow[t]{2}{*}{ logincome } & 0.082 & 0.082 & 0.089 \\
\hline & $(-1.4)$ & $(-1.47)$ & $(-1.35)$ \\
\hline \multirow[t]{2}{*}{ han } & -0.127 & -0.112 & -0.171 \\
\hline & $(-0.57)$ & $(-0.51)$ & $(-0.56)$ \\
\hline \multirow[t]{2}{*}{ party } & $-0.495^{*}$ & -0.456 & $-0.593 *$ \\
\hline & $(-1.81)$ & $(-1.54)$ & $(-1.81)$ \\
\hline \multirow[t]{2}{*}{ health } & -0.031 & -0.03 & -0.016 \\
\hline & $(-0.44)$ & $(-0.42)$ & $(-0.19)$ \\
\hline \multirow[t]{2}{*}{ marital } & & -0.113 & $0.103^{*}$ \\
\hline & & $(-1.10)$ & $(-1.89)$ \\
\hline \multirow[t]{2}{*}{ poverty } & & & 0.067 \\
\hline & & & $(-0.4)$ \\
\hline \multirow[t]{2}{*}{ Constant } & $1.876 * *$ & $1.540 * *$ & 0.866 \\
\hline & $(-2.53)$ & $(-2.37)$ & $(-1.16)$ \\
\hline $\mathrm{N}$ & 485 & 485 & 365 \\
\hline
\end{tabular}

* Denotes $10 \%$ significance level.

** Denotes $5 \%$ significance level.

*** Denotes $1 \%$ significance level.

\subsection{Government Mechanism of Land Property Right on Migration}

The migration of rural population to urban areas will lead to a decrease in the population of rural households. If the decrease in population will increase the land expropriation risk of rural households, then there will be a mechanism for government land expropriation to influence population migration decisions. The reason is that once the rural population moves to urban areas, the increased risk of land expropriation will make the rural population who intends to migrate have to consider the opportunity cost, which will make some people give up the idea of moving to urban areas. Some scholars believe that the impact of increased risk is similar to the impact of taxation on immigration (Mullan and Grosjean, 2011), which reduces the likelihood of immigration. Table 1 lists information about useful variables.

\subsubsection{Basic Regression}

In order to evaluate the impact mechanism of government land requisition on population migration, we use a dummy variable which is "has your family's land been requisitioned by the government since 1978" as the key variable, using gender, education level, and whether there is a convenient place for medical treatment As an 
auxiliary variable. Use the PROBIT model to evaluate the impact of increased land ownership security on population migration. The model uses STATA15 to estimate. The basic regression model for government mechanism is:

Migration $=\beta_{0}+\beta_{1}$ expropriation $+\beta_{2}$ gender $+\beta_{3}$ edu

$+\beta$ 4hospital $+\square$

The Basic Regression column in Table 5 shows the results of the regression analysis. It is consistent with the results of the previous speculation. The government land acquisition mechanism has a significant impact on population migration. The negative correlation coefficient indicates that the smaller the risk of land acquisition, the more likely it is to promote the population from The countryside moved to urban areas. Like the experimental method of the market mechanism, in order to obtain a more rigorous conclusion, we need to conduct robustness checks on the mechanism of government land expropriation on population migration.

\subsubsection{Robustness Checks}

In order to test whether the correlation between government land expropriation and migration is stable, I set up a robustness check. I added age, ethnicity, province of residence, and household income as variables to construct a robustness check. The experiment results are recorded in robustness check1-4 of table 5 .

Table 5. Estimates of Migration Decision (Government Mechanism)

\begin{tabular}{|c|c|c|c|c|c|}
\hline VARIABLES & $\begin{array}{c}\text { Basic } \\
\text { Regression }\end{array}$ & $\begin{array}{c}\text { Robustness } \\
\text { Check1 }\end{array}$ & $\begin{array}{c}\text { Robustness } \\
\text { Check2 }\end{array}$ & $\begin{array}{c}\text { Robustness } \\
\text { Check3 }\end{array}$ & $\begin{array}{c}\text { Robustness } \\
\text { Check4 }\end{array}$ \\
\hline \multicolumn{6}{|l|}{ migration } \\
\hline \multirow[t]{2}{*}{ expropriation } & $-0.183 *$ & $-0.215 * *$ & $-0.250 * *$ & $-0.248 * *$ & $-0.259 *$ \\
\hline & $(-1.78)$ & $(-2.08)$ & $(-2.21)$ & $(-2.20)$ & $(-1.94)$ \\
\hline \multirow[t]{2}{*}{ gender } & $0.808 * * *$ & $0.983 * * *$ & $0.973 * * *$ & $0.973 * * *$ & $0.955 * * *$ \\
\hline & $(-11.14)$ & $(-13.01)$ & $(-11.22)$ & $(-11.23)$ & $(-8.81)$ \\
\hline \multirow[t]{2}{*}{ edu } & $0.089 *$ & -0.04 & -0.01 & 0.00 & -0.06 \\
\hline & $(-1.65)$ & $(-0.79)$ & $(-0.09)$ & $(-0.06)$ & $(-0.80)$ \\
\hline \multirow[t]{2}{*}{ hospital } & 0.10 & 0.00 & -0.02 & -0.02 & -0.10 \\
\hline & $(-0.84)$ & $(-0.03)$ & $(-0.13)$ & $(-0.14)$ & $(-0.65)$ \\
\hline \multirow[t]{2}{*}{ age } & & $-0.038 * * *$ & $-0.037 * * *$ & $-0.037 * * *$ & $-0.040 * * *$ \\
\hline & & $(-8.87)$ & $(-7.56)$ & $(-7.56)$ & $(-6.51)$ \\
\hline \multirow[t]{2}{*}{ han } & & & 0.12 & 0.12 & 0.18 \\
\hline & & & $(-0.90)$ & $(-0.90)$ & $(-1.18)$ \\
\hline \multirow[t]{2}{*}{ prov } & & & & 0.00 & 0.00 \\
\hline & & & & $(-0.34)$ & $(-0.51)$ \\
\hline \multirow[t]{2}{*}{ logincome } & & & & & 0.03 \\
\hline & & & & & $(-0.82)$ \\
\hline \multirow[t]{2}{*}{ Constant } & $-0.501 * * *$ & $1.946 * * *$ & $1.732 * * *$ & $1.760 * * *$ & $1.923 * * *$ \\
\hline & $(-3.73)$ & $(-6.34)$ & $(-4.97)$ & $(-4.86)$ & $(-3.83)$ \\
\hline $\mathrm{N}$ & 1343 & 1430 & 1403 & 1403 & 931 \\
\hline
\end{tabular}

* Denotes $10 \%$ significance level.

** Denotes $5 \%$ significance level.

*** Denotes $1 \%$ significance level.

The results of the robustness check are very optimistic, and the correlation between government land expropriation and migration has been verified. In terms of the correlation between other variables and migration, we have observed that male and younger age is positively correlated with migration, which coincides with some conclusions in the market mechanism. 


\section{ANALYSIS}

\subsection{Market Channel}

In Table.4, the chuzubi variable has a significant and positive correlation with migration, proves the previous hypothesis on how the market mechanism affects population migration: if the land is allowed to lease or land lease market is active, villagers can lease their land out to reduce the opportunity cost of giving up farming, thereby encouraging the population to move to urban areas.

\subsection{Expropriation (Government) Channel}

In table.5, the coefficient of the expropriation variable on migration is negative and significant, indicating that the risk of land expropriation is negatively related to population migration, which also confirms the speculation about how the government mechanism affects the migration of urban and rural populations: if the land property rights of villagers can be protected more, rural population will have a higher tendency to migrate. Under China's current land system, farmers have the right to use the land, but the ownership of the land belongs to the government, and the government can compulsorily expropriate the farmers' idle land due to the needs of urban construction and other reasons. Therefore, in order to avoid land expropriation, rural people may choose to stay in the local farming area, which leads to a negative correlation between land expropriation and migration.

\section{CONCLUSION}

\subsection{What Have Done in This Paper}

This paper studies the impact of the land system on rural-urban migration. First, this paper gives a general description of China's land system and summarizes the views of Chinese and foreign scholars on land ownership and population mobility. Through summary and analysis, divided the impact mechanism of the land system on population migration into two categories: market mechanism and government land expropriation mechanism. Selected the ratio of land rented and whether the land has been acquired by the government as the main variables. For data analysis, the author chose the CHARLS database that the Peking University Social Development Research Institute made public. To form a complete experiment, this paper chose some factors that may also affect population mobility as auxiliary variables and applied them to the regression model of the two mechanisms at the same time. Considering the credibility of the experiment, the author tested the robustness of the two models separately. Considering the two-way causality that may exist in the market mechanism, the author chose whether a household has agricultural production equipment as an instrumental variable for the regression model of the market mechanism, the endogeneity test was carried out. In the end, the regression results proved the hypothesis in 2.2.2.

\subsection{What the Conclusion is}

Experimental results show that in the market mechanism, increased land lease rights or an active land lease market promotes rural-urban migration; in the government mechanism, enhanced land ownership guarantees also contribute to rural-urban migration.

\subsection{Policy Implication}

Since the market mechanism and the land acquisition mechanism can act on population migration at the same time, the government can have a lot of policy flexibility. The government can intervene in the migration of ruralurban population through these two channels, thereby regulating the population balance and economic development of the target area. Considering that China's current urbanization rate is only $60 \%$, these two identified channels will play some guiding roles in China's future urbanization process. For example, improve the rural land lease market, encourage largescale planting, or give farmers more land ownership security.

\subsection{What Could be Done in the Future}

Considering the mandatory and controllability of policies, exploring more details of government mechanisms will have more practical significance than studying market mechanisms. Usually, after the government's compulsory expropriation of land, only very meager subsidies will be given to land users. Because of the positive correlation between household income and population migration in the regression model, I propose a hypothesis: whether increasing the compensation for land expropriation can make the effect of land expropriation on population migration change from negative to positive. Verification of this conjecture may require more data, such as the specific amount of government compensation for land acquisition, or other empirical analysis between regions with greater differences in compensation for land acquisition.

\section{REFERENCES}

[1]. Yulin Wang. "The Economic Analysis of China's Population Migration." Chinese and Foreign Entrepreneurs 2 (2014).

[2]. Guanghua Wan. "2030: China's urbanization rate will reach 80\%." International Economic Review 6 (2011): 99-111.

[3]. Ge Song. "Research on Land Use in the Process of 
Urbanization in China." Northeast Agricultural University (2004)..

[4]. Xu Zhang. "The Development Model of China's Agricultural Economy: The Controversy between the Small Farmer Economy and the Collective Economy Since the Founding of New China." Journal of Neijiang Teachers College 2 (2016).

[5]. Xiangming Dou. An Empirical Study of Modern Chinese Rural Land Property Rights System. Diss. Nanjing Normal University, 2013.

[6]. Guangdong Liu, and Jiumiao Cheng. "Theories and Practices of China's Rural Land System Changes Since 1949." China Rural Observation 2 (2007).

[7]. Chongpu Luo. "Research on the Change and Innovation of my country's Rural Land Property Right System: Based on the Perspective of Institutional Economics." Local Finance Research 3 (2009).

[8]. Yongxiu Bai, and Pan Liu. "The historical evolution of rural labor mobility since the founding of the People's Republic of China: Based on the perspective of promoting the household contract responsibility system." Fujian Forum (Humanities and Social Sciences Edition) 3 (2019).

[9]. Dan Chen. "Thinking and Suggestions on the Protection of Permanent Basic Farmland." Land Resources 9 (2017).

[10].Xiaojun Chen. "The Ideas and Framework for the Reform of my country's Rural Land Legal System." Legal Research 4 (2014): 11-12.

[11].Zhonghua Sun. "Thoughts on the Policy and Legal Issues Concerning the "Three Rights Separation" of Rural Land." Journal of the Academy of Management Cadres of the Ministry of Agriculture 1.4 (2015).

[12].Fei Gao. "The Legal Interpretation and Institutional Implication of the "Three Rights Separation" of Rural Land." Legal Research 3.3 (2016).

[13].Linyi Zheng, and Yingliang Zhang. "New China's Agricultural Land Property System Changes: History, Motivation and Enlightenment." Journal of Southwest University (Social Science Edition) 45.1 (2019): 46-54.

[14].Liming, Wang, and Zhou Youjun. "A Discussion on Improving the Right System of Rural Land in China [J]." China Legal Science 1 (2012).

[15].Wu, K. N., and S. L. Ma. "Reform of rural land property right institution in China." China Land Science 4 (2005): 38-42.
[16].Zhou, Yang, Xunhuan Li, and Yansui Liu. "Rural land system reforms in China: History, issues, measures and prospects." Land Use Policy 91 (2020): 104330.

[17].Biliang, Luo. "On the Fuzziness of the Property Right of Agriculture Land: a Conceptual Frame and Explanation [J]." Academic Research 12 (2011).

[18].Rui, W. E. N. "The Ideological Obstacles for Furthering the Reform of Rural Land Property Right [J]." Journal of Fujian Normal University (Philosophy and Social Sciences Edition) 2 (2006).

[19].Guanghua Wan." 2030: China's urbanization rate reaches 80\%." International Economic Review 6 (2011): 99-111.

[20].Kung, James Kai-sing. "Choice of Land Tenure in China: The case of a county with quasi-private property rights." Economic Development and Cultural Change 50.4 (2002): 793-817.

[21]. Shengping Gao. "The Allocation of Legal Rights of Contracted Land after the Revised Rural Land Contract Law." Legal Research 41.5 (2019): 44-62.

[22].Deininger, K., \& Jin, S. (2009). Securing property rights in transition: Lessons from implementation of China's rural land contracting law. Journal of Economic Behavior and Organization, 70(1-2), 2238.

[23].Tao, Ran, and Zhigang Xu. "Urbanization, rural land system and social security for migrants in China." The Journal of Development Studies 43.7 (2007): 1301-1320.

[24].Zhang Quanjing, and Wang Wanmao. Theoretical Investigation and Reform Thinking of my country's Land Requisition System. Diss. 2003.

[25].Zhao Jianying, Li Na, Peng Wenzhuo. "After 80 million people enter the city." Workers' Daily (2018$3-25(02))$

[26].Mullan, Katrina, Pauline Grosjean, and Andreas Kontoleon. "Land tenure arrangements and ruralurban migration in China." World Development 39.1 (2011): 123-133. 